\title{
ON THE ORDER OF COMPLEMENTS IN LATIN SUPPORT VERB CONSTRUCTIONS: A MULTIDIMENSIONAL APPROACH
}

\author{
Elena Zheltova
}

Saint Petersburg State University,

7-9 Universitetskaya nab., St. Petersburg, 199034 Russia, Russian Federation; e.zheltova@spbu.ru

The article investigates the ordering of complements in Latin support verb constructions (SVC) of the type bellum inferre or insidias facere with prototypically trivalent verbs, which can either keep or lose the third valency in such constructions. After the brief synopsis of the issues regarding general aspects of the SVCs, the author focuses on the order of the Direct and Indirect objects within the nine constructions (304 occurrences in total) taken from the works of Classical Latin writers. The theoretical background of the analysis applied is the idea of interaction and competition between the three language dimensions, i. e. semantic, pragmatic and deictic-denotative ones, which can determine various orderings of the complements in their relation to each other. On the basis of a previous corpus study concerning the argument structure of Latin trivalent verbs, the author considers the order Direct-Indirect object (DI) as unmarked (neutral), while the opposite order ID as resulting from either special deictic-denotative properties of the arguments or pragmatic factors. As regards the deictic-denotative properties, they depend on the place occupied by the noun or the pronoun in the animacy hierarchy. The promotion of the Indirect object to the priority position is explained by the animacy of its denotatum or by the status of speech act participant, if it is expressed by a personal / reflexive / anaphoric pronoun.

The author analyzes the order of the Direct and Indirect objects in the nine support verb constructions selected from the works by Caesar, Cicero and Sallust (304 occurrences in total). The analysis demonstrates that the order ID is attested three times as often as the opposite order DI, because the Indirect objects are usually animate or pronominal in the constructions of this type. In some cases, however, the pragmatic factors such as focus, contrast or emphasis may also influence the ordering. The findings are represented in the table and are followed by the examples.

Keywords: Latin support verb constructions, constituent order, syntax, pragmatics, deictic-denotative properties of the constituents, valency center.

\section{Introduction ${ }^{1}$}

In Latin, as well as in many other languages, there are analytical constructions consisting of verbs with "bleached" semantics and abstract nouns, which bear the main lexical meaning. Such verbal constructions initially were studied on the base of the French language ${ }^{2}$ and were called "les construction à verb support", but since the ninetieth, they have drawn attention of the experts in other languages including Latin, and became very popular as an object of investigation under a variety of names: periphrastic constructions, collocations, support verb constructions (SVC henceforth), light verb constructions, verbo-nominal constructions, Functionsverbgefüge. The study of this phenomenon in such corpus language as Latin is considered to be a matter of great importance from the typological point of view (Baños 2012, 37). Normally, SVCs in Latin are the combinations

${ }^{1}$ I would like to express my gratitude to Olga Spevak for the invitation to participate in the Journée détude: Les constructions à verbe support en latin in September 2016, Toulouse, where I presented a part of this study. I am also grateful to Tatiana Nikitina and Evgenij Filimonov whose useful remarks aided in revising this article for publication.

2 See Gross 1981; Giry-Schneider 1987.

(c) St. Petersburg State University, 2016 
of the verbs facere, dare, ferre (afferre), capere, agere, gerere and some others with different abstract or verbal nouns. In such constructions, the verb does not completely lose its semantics (unlike in the idioms of the type morem gerere), but it weakens - to some extent - its lexical meaning, while keeping the grammatical meaning of person, number, tense, aspect, mood and voice. Its main contribution is to actualize the process (Gross 2004, 167; Spevak 2014, 202).

Typically, these constructions are analytical correlates to the simple verbs with similar semantics: insidias facere - insidiari, spem capere - sperare, usum habere - uti etc.

What is the existence of such analytic constructions in a synthetic language like Latin determined by? The researchers answer this question in different ways.

If SVC has a simple verbal correlate of the same root (e.g. vitam ago - vivo, fugam facio - fugio), the right of this construction to exist is explained by the need for the expression of different kinds of nuances (Flobert 1996, 196; Gross 2004, 167), as well as by the fact that the analytical constructions give an opportunity to modify the noun by means of adjectives or pronouns, and therefore, to refine or make more precise the predicate's meaning, as in example (1), where the SVC messim facere with the modifier primam is used instead of the simple verb metere (Pinkster 2015, 74):

(1) ardius messim primam eius facere oportebit ... (Columella Rust. 2, 10, 28)

Apart from semantics, there may also be a syntactic factor motivating the use of complex construction instead of a simple verb, as exemplified in (2):

(2) Messi facta spicilegium venire oportet (Varro Rust. 1, 53, 1)

In this clause, the Ablative absolute would have been impossible with the simple verb metere (Pinkster 2015, 76).

If there is no simple verb with a certain meaning in a language, the SVC is believed to compensate for its lack, as verba facere 'to speak in a public place.'

Some SVCs can be considered as substitutes of the passive forms for deponent verbs: admiror - in admiratione esse, obliviscor - in oblivionem adduci / de memoria excidere (Flobert 1996, 194).

Previously, it has been thought that the verbo-nominal constructions are characteristic of the colloquial style (Hofmann, Szantyr 1972, 754-755), but now this opinion is not so popular (Pinkster 2015: 76): SVCs, indeed, look appropriate in the philosophical writings of Cicero as well as in his letters, or didactic treatises of Columella and Varro, or in the Plautus' and Terence's comedies. idioms?

How the support verb constructions can be identified and distinguished from the

In literature on the topic, a variety of criteria can be found. Thus, Pierre Flobert (1996, 195-196) points out inter alia the following properties of SVCs:

1) SVCs can be transformed into a passive (insidias facere / insidiae fieri),

2) some SVCs have "conversion" pairs (fidem dare - fidem accipere),

3) the same noun can be combined with different support verbs (spem capere / facere / habere, afferre, dare; bellum inferre, gerere, facere). ${ }^{3}$ The nuances of meaning provided by these verbs are not always obvious and concern mainly the aspectual differences: one

3 The Tatiana Taous' analysis of the collocations with the noun bellum and different support verbs showed that the choice of a verb can depend on the literary genre: whereas in prose the verb gerere oc- 
can therefore distinguish between the durative agere, punctive facere, terminative gerere, ingressive ferre etc.,

4) the set of SVCs in a language is constantly updated, as it is seen from Petronius (42, 1: staminatas ducere; 34, 7; 73, 6: tangomenas facere) and Egeria (9, 1: vigilias agere; 37, 7: spiritum reddere).

Some other criteria for SVC identification were proposed by Gaston Gross in his Introduction to the special edition of Linguisticae Investigationes dedicated to support verb constructions in different languages (Gross 2004, 168). He drew attention to the following properties of SVCs:

1) the construction can be converted into a relative clause: insidias facere - insidias, quas Clodius Miloni fecit; ${ }^{4}$

2) the noun can be modified by an adjective or a possessive pronoun: bellum gerere eius bellum, gratias agere - maximas gratias;

3 ) the verb cannot be subject to nominalization: insidias facere / parare — ${ }^{\star}$ factio / paratio insidiarum (??).

These properties do not hold for idioms, and consequently can serve to distinguish these two types of constructions. Compare, e.g., morem gerere — ${ }^{\star}$ mos, quem ...gerit (??)

G. Gross also recommends to separate the support verb construction both from the light verb constructions of the Anglo-Saxon tradition and from German Functionsverben, since they may include des constructions de nature adjectival (e. g., être en mouvement) or causative ones (e. g., mettre en mouvement) (Gross 2004, 167). This point is supported by André Valli $(2007,45)$, who insists on distinguishing between les construction verbales figées (les locutions verbales in Gross' terms $(2004,168)$ ) and les constructions à verbe support.

Note, however, that the criteria suggested by scholars do not always work, and a general consensus on this point has not been reached.

One of the most interesting problems concerning verbo-nominal constructions is syntactic incorporation, particularly if both a SVC and the verb with incorporation coexist in a language. Emanuela Marini (2015) considers the constructions bellum gerere and ludos facere as full semantic equivalents of the verbs belligero and ludificor. According to Pierre Flobert $(1996,197)$ and Jose Miguel Baños $(2012,2013)$, incorporation is the last stage in the evolution of verbo-nominal constructions. Sometimes the two similar constructions can undergo completely different syntactic processes resulting in the SVCs with different levels of grammaticalization, as, for example, ludos facere. Baños demonstrated that, on the one hand, the construction ludos facere + Acc. 'to make a fun of smb' has converted into the incorporating verb ludificari, because the support verb facere lost its original meaning, and the whole SVC underwent full grammaticalization (Baños 2012, 47 ); on the other hand, the homonymous construction ludos facere + Dat. with a completely different meaning 'to organize the game in someone's honor', was not subjected to grammaticalization and incorporation, because the verb facere in this case preserved its meaning. According to Baños $(2012,55)$, these two constructions are the two poles on the continuum: from the SVC with the verb which has not lost its semantics to the structure subjected to syntactic incorporation. Interestingly, close connection between a verb and

curs more often, in poetry the variety of verbs is considerable (movere, facere, ducere, ferre, gerere) (Taous 2015, 279).

${ }^{4}$ For the purpose of clarity, I substituted the author's French examples for the Latin ones. 
a noun does not always result in incorporation, if this connection is lexical rather than syntactic one, as in the verb manumittere 'to free a slave' (Fugier 1994, 88).

As it is seen from the above observation, the Latin language produced homonymous collocations with completely different meaning. This difference is manifested in their unequal syntactic behavior, which seems to be another interesting topic related to verbonominal constructions. The SVC fidem facere, for example, has two different meanings and hence, two types of extension. When it means 'to lend credence', it is used with the dative complement, as is exemplified in (3):

(3) ... Quoniam auribus vestris propter incredibilem magnitudinem sceleris minorem fidem faceret oratio mea (Cic. Cat. 3, 4, 7).

When, however, the construction has the causative meaning 'make believe', it is accompanied by the AcI, as in (4):

(4) Etenim si populo consulis ... fac fidem te nihil nisi populi utilitatem et fructum quaerere (Cic. Leg. agr. 2, 22, 2).

The types of complements in SVCs and the number of valencies of both a verb and a noun is another interesting topic which I would like to consider in detail. It is the alignment of the complements or, in other words, their order within the SVCs that will be of my particular interest.

\section{Valency center, number of arguments and constituent order in SVCs: a brief synopsis}

The number of valencies of support verbs and nouns in SVCs as well as the ordering of the constituents is a very topical issue. In recent years we have witnessed a lot of studies on the topic.

According to Hannah Rosén (1981: 144), the centre of valency in verbo-nominal constructions is either the noun, the underlying verb or the whole syntactic construction. The idea of a whole construction as valency center is supported by Olga Spevak (2010, 125-126) and Roland Hoffmann $(2015,368)$, who consider the noun and the verb as a pragmatic unit, in which the two components are in close connection with each other. Combining a verb and a noun in the syntactic unity can reduce a number of the verb valencies and thus change the verb's argument structure. In the construction insidias facere 'to intrigue against smb', the verb facere 'to do' is supposed to admit three arguments: Agent, Patient and Recipient, but in fact, the third argument depends on the noun insidias 'intrigue' or on the construction as a whole rather than on the verb. For this reason, the proper question to the clause in (5) should be 'what happened to Milo' or 'whom did Clodius intrigue against' rather than 'what did Clodius do to Milo':

(5) Clodius insidias fecit Miloni (Cic. Mil. 60, 5)

There is no doubt that the number of verbal valencies is often reduced in SVCs, but it is also clear that to find the valency center of a SVC is not always an easy task. In my study, I am going to focus on the constructions with prototypically trivalent verbs, e. $\mathrm{g}$. 
facere / agere 'to do smth for smb', dare 'to give smth to smb', (in-, ad-) ferre 'to bring smth to smb. Each of them admits complements in the accusative and in the dative, with prototypical semantic roles of Patient and Recipient, but in fact, as Harm Pinkster points out, in these combinations, further arguments do not depend on the verb, but rather on the noun (Pinkster 2015: 74).

If we take into account the reduction of the verb's valencies in SVCs, it seems reasonable to talk about the argument structure in syntactic, rather than semantic terms (i. e. to use the terms "Direct (D) and Indirect (I) objects", or "complements" instead of Patient and Recipient). ${ }^{5}$

The next interesting issue is how consistent or, conversely, inconsistent the word order in such constructions is. This question has been repeatedly raised by scholars especially in its relation to the level of cohesion between the constituents in SVCs, and therefore, to the degree of grammaticalization. In other words, the more consistent the word order in SVC, the further SVC has proceeded along the path of grammaticalization.

The position of the verb $(\mathrm{V})$ and the noun $(\mathrm{N})$ in verbo-nominal constructions has been studied in detail by Olga Spevak (2010: 125-131) who applied the pragmatic approach to the constituent order in classical Latin prose. Spevak believes that in verbonominal constructions neither the verb nor the noun is a candidate for Focus, but they function together as a pragmatic unit (Spevak 2010, 125-126). A detailed examination of 178 constructions taken from Caesar, Sallust and Cicero allowed her to conclude that ordering of the main components is not fixed, but demonstrates a strong tendency to be $\mathrm{NV}$, since the noun precedes the verb in $71 \%$ of cases. Spevak also notes that the more the number of complements in the construction is, the greater the amount of variations that can be observed. In general, she comes to the important - in view of my study - conclusion that the relative ordering of the verb and the noun in verbo-nominal constructions cannot be definitively established, because their behavior depends on their syntactic capacities and their semantic properties (Spevak 2010, 131). Whereas the position of $\mathrm{V}$ and $\mathrm{N}$ in SVCs is investigated rather well, ${ }^{6}$ the ordering of the other constituents is not so clear. In the following sections of my article, I am going to examine the order of the complements within the verbo-nominal constructions and to establish whether the syntactic, semantic or other properties of the constituents in question are crucial for the ordering.

\section{The Ordering of Direct and Indirect objects in support verb constructions}

In view of these data, I will proceed to the main purposes of my study: first, to reveal what the order of Direct and Indirect objects in SVCs depends on, and second, to try to establish what language processes or tendencies stand behind it.

As it has been mentioned above, I will concentrate on the constructions with the support verbs which are prototypically trivalent or, at least, admit the complements in the accusative and the dative (dare, (ad-, in-) ferre, facere, parare, gerere). The question

\footnotetext{
${ }^{5}$ Since Latin is a pro-drop language, in this study I will ignore the position of the first argument (Agent, or Subject).

${ }^{6}$ See Spevak 2010, 126; Marini 2015, 120.
} 
about their ordering is closely related to the general problem of verb argument structure in Latin, which I analyzed in my previous study (Zheltova 2014). ${ }^{7}$ The examination of the verb mitto 'to send' and some other trivalent verbs with Direct (D) and Indirect (I) objects clearly showed that the order of $\mathrm{D}$ and I in relation to each other is a result of the competition between different linguistic dimensions, i. e. syntactic, pragmatic and deictic-denotative ones. The neutral order of the arguments determined exclusively by the semantic roles was found to be DI (i. e. Direct - Indirect object), but it can be easily converted into $I D$ under the influence of both pragmatic factors and deictic-denotative properties of the arguments including animacy and the status of speech act participants. ${ }^{8}$ Having analyzed different combinations of nouns with personal pronouns as well as personal / reflexive / anaphoric pronouns with each other, I came to the conclusion that the priority of I over $\mathrm{D}$ which contradicts the neutral order, can be explained by the higher position of animate nouns and pronouns in the animacy hierarchy.

Now my aim is to examine whether such multidimensional approach holds for support verbs.

In this study, I will restrict my corpus to the three authors of the classical period Caesar, Cicero and Sallust. Later, I am going to extend my empirical base by adding the authors belonging to the other periods of Roman literature, to look at the phenomenon in the diachronic perspective. As regards the collocations, I selected 9 SVCs corresponding to the pattern 'support verb + noun in Acc.' The eight collocations admit complements in the dative, and only one (bellum gerere) governs prepositional phrases cum + Ablative or contra + Accusative.

\section{Methodology}

For the purpose of my analysis, I used the electronic database PHI- $5 .{ }^{9}$ I examined 9 constructions with support verbs agere, dare, (ad-, in-)ferre, facere, parare, gerere (304 occurrences in total) found in the works of Caesar, Cicero and Sallust. The aim of this examination is to reveal the order of Direct and Indirect objects in each construction without taking into account, whether the Indirect object is governed by the verb or by the noun, or by the structural unity of both, and to realize, what variations in ordering depend on. The data are represented in the table. ${ }^{10}$

In the table, the three columns are occupied by the combinations of the Direct object promoted in the first position, with animate, inanimate and pronominal Indirect objects respectively; the following three columns are given to the combinations of animate, inanimate and pronominal Indirect objects with the Direct object. The two right columns contain the statistics of correlation between the combinations $D I$ and $I D$, and the total number of occurrences for each verbo-nominal construction.

\footnotetext{
7 Желтова Е.В. Дейктико-денотативная иерархия и конструкции с трехвалентными глаголами в латинском языке. Philologia classica 2014, 9, 228-247.

${ }^{8}$ On this multidimensional approach see Zheltov 2008, 150-162 (Желтов А. Ю. Языки нигер-конго. Структурно-динамическая типология. СПб., Изд-во Санкт-Петербургского Университета, 2008).

9 A resource prepared by the Packard Humanities Institute.

${ }_{10}$ The abbreviations in the table: D - Direct Object, I - Indirect Object, an — animate, inan - inanimate, pro - personal / reflexive / anaphoric pronoun.
} 


\begin{tabular}{|l|c|c|c|c|c|c|c|c|}
\hline & DIan & DIinan & DIpro & IanD & IinanD & IproD & DI:ID & Summa \\
\hline Gratias agere & 9 & 1 & 7 & 33 & 1 & 80 & $17: 114$ & 131 \\
\hline Auxilium ferre & 2 & 0 & 1 & 13 & 3 & 3 & $3: 19$ & 22 \\
\hline $\begin{array}{l}\text { Dolorem dare/afferre/ } \\
\text { facere }\end{array}$ & 0 & 0 & 1 & 0 & 0 & 7 & $1: 7$ & 8 \\
\hline Iniuriam facere & 8 & 1 & 3 & 6 & 2 & 4 & $12: 12$ & 24 \\
\hline Bellum inferre & 9 & 2 & 2 & 13 & 4 & 6 & $13: 23$ & 36 \\
\hline Bellum gerere & 13 & 0 & 1 & 23 & 1 & 4 & $14: 28$ & 42 \\
\hline Bellum facere & 6 & 0 & 0 & 2 & 0 & 1 & $6: 3$ & 9 \\
\hline Spem afferre / proponere / dare & 5 & 0 & 7 & 1 & 0 & 3 & $12: 4$ & 16 \\
\hline Insidias facere/ parare & 6 & 2 & 0 & 4 & 0 & 4 & $8: 8$ & 16 \\
\hline Summa & 58 & 6 & 22 & 95 & 11 & 112 & $86: 218$ & 304 \\
\hline$\%$ & $19 \%$ & $2 \%$ & $7 \%$ & $31 \%$ & $4 \%$ & $37 \%$ & $28 \%: 72 \%$ & $100 \%$ \\
\hline
\end{tabular}

The Odering of Direct and Indirect objects within the support verb constructions.

It is worth noting that the participants $\mathrm{D}$ in the table are always inanimate, whereas the participants I can be either animate or inanimate, or pronominal, so the ordering of the participants in each construction is expected to depend on the properties of the latter rather than the former.

\section{Results}

\subsection{Preferred order of the complements in the selected constructions}

The analysis of the combinations represented in the table highlighted the following points:

1) the pattern $I D$ is attested in $72 \%$ of cases, i. e. almost three times as often as the opposite order DI (28\%), although it is DI that is believed to be neutral and most frequent in the construction with typical trivalent verbs;

2) the combinaiton IproD, with pronominal argument in a prominent position, is an absolute champion in number, since it occurs in $37 \%$ of cases. This can be explained by the fact that personal / reflexive pronouns occupy the highest position in the animacy hierarchy as speech act participants (the so-called locutors); ${ }^{11}$

3 ) the combination IanD ranks next in frequency of occurrences (31\%), because animate nouns also tend to occupy the higher levels of the animacy hierarchy. Interestingly, names of animals do not occur as dative complements, only human names and collective nouns, such as senatus, populus etc., which in Latin, unlike in Russian and some other languages, are thought to be animate (Zheltova 2015, 255-256 ${ }^{12}$ ) and therefore, obtain a very high position in the empathy hierarchy of the ancient Romans.

To sum up, animacy clearly makes a contribution to the ordering of constituents in verbo-nominal constructions, hence, we must agree that the deictic-denotative dimension prevails over the semantic one in Latin SVCs.

\footnotetext{
11 About animacy and personal hierarchies, see Zheltova 2014, 230-231.

12 Желтова Е.В.Почему «река» одушевленнее «рака»: о нестандартных случаях проявления категории одушевленности в латыни. Philologia classica 2015, 10, 245-266.
} 
The examples of support verb constructions in the table are given below:

(6) Agit hominibus gratias et eorum benivolentiam erga se diligentiamque conlaudat (Cic. Verr. 2, 5, 161).

(7) Ubii autem, qui uni ex Transrhenanis ad Caesarem legatos miserant, amicitiam fecerant, obsides dederant, magnopere orabant, ut sibi auxilium ferret (Caes. BGall. 4, 16, 5)

(8) ...neque enim tibi haec res adfert dolorem, sed quandam incredibilem voluptatem (Cic. Cat. 1, 25, 3)

(9) ...si iniuriam tibi factam quereris, defendam et negabo (Cic. Div. Caec. 58, 2)

(10) ...infer patriae bellum, exsulta impio latrocinio (Cic. Cat. 1, 23, 8)

(11) Cum Armeniorum rege Tigrane grave bellum nuper ipsi diuturnumque gessimus (Cic. Sest. 58, 8)

(12) ...bellum ego populo Romano neque feci neque factum umquam volui (Sall. Iug. 110, 6, 2)

(13) ... hic dies meaque contentio atque actio spem primum populo Romano attulit libertatis reciperandae (Cic. Fam. 10, 28, 2)

(14) Nam Pompeius haec intellegit nobiscumque communicat, insidias vitae suae fieri (Cic. QFr. 2, 3, 4)

\subsection{Explaining different orders of complements: a pragmatic approach}

If we look closely at the penultimate right columns of the two tables, it will be obvious that the choice of the orderings varies significantly in different SVCs. Some of them distribute the orders $I D$ and $D I$ almost equally, without preferences, like iniuriam facere (12: 12), insidias facere / parare (8: 8). Others prefer the order ID, like gratias agere (114 occurrences out of 131), auxilium ferre (19 out of 22), dolorem dare / afferre / facere (7 out of 8), auxilio esse (13 out of 19), or, on the contrary, choose the opposite order DI: bellum facere (6 out of 9), spem afferre (12 out of 16). Many of them demonstrate a very high level of consistency in ordering that seems even suspicious in a language with the syntactically free constituent order. How can this be explained?

It is obvious that neither the syntactic, nor the deictic-denotative dimension suffices for explaining this phenomenon, so a third - pragmatic - dimension should be involved.

To prove this, let us first concentrate on the most frequent construction in my corpus - gratias agere, which definitely prefers the order ID. The special status of this SVC needs no explanation: what construction appears more often in any language than the expression of gratitude? It is natural that in the majority of cases, it occurs with the animate dative complements (129 out of 131 in my corpus), and in a considerable part of them, the complements are expressed by personal pronouns. As Spevak pointed out (2010, $94-$ 95), if such pronouns are used in an oblique case, their placement in the clause is variable and not necessarily initial, because they do not have a special pragmatic function. It means that my hypothesis about the priority of the deictic-denotative dimension, which determines the initial position of the pronouns, is credible. Nevertheless, in some cases the pragmatic dimension does really work as well.

One of such cases is exemplified in (15), where Cicero chose the order DI, which is not typical for the constructions with pronominal Indirect objects:

(15) qui etiam gratias tibi agere debeo quod me ex fortissimorum civium numero seiungendum non putasti (Cic. Vat. 26, 2) 
'When I ought rather to return you thanks, for having thought me deserving of not being separated from the number of gallant and virtuous citizens' (transl. by C. D. Yonge).

The constituent gratias is emphatic, that is why it occupies the initial position, ${ }^{13}$ before the personal pronoun tibi, which does not have special pragmatic function in this context.

The importance of pragmatic dimension is clearly seen in comparison of examples with the same constituents expressed by the same nouns, as in (16), (17), and (18):

(16) quem cum supremo eius die Maximus laudaret, gratias egit dis immortalibus, quod ille vir in hac re publica potissimum natus esset (Cic. Mur. 75, 2)

'a man with respect to whom Maximus, when he was pronouncing his funeral panegyric on the day of his death, expressed his gratitude to the immortal gods for having caused that man to be born in this republic above all others' (transl. by C. D. Yonge).

(17) at vero aut honoribus aucti aut re familiari, aut si aliud quippiam nacti sumus fortuiti boni aut depulimus mali, tum dis gratias agimus, tum nihil nostrae laudi adsumptum arbitramur (Cic. Nat. D. 3, 87, 6)

'On the other hand when we achieve some honour or some accession to our estate, or obtain any other of the goods or avoid any of the evils of fortune, it is then that we render thanks to the gods, and do not think that our own credit has been enhanced' (transl. by H. Rackham).

(18) num quis quod bonus vir esset gratias dis egit umquam? (Cic. Nat. D. 3, 87, 8)

'Did anyone ever render thanks to the gods because he was a good man?' (transl. by H. Rackham).

In (16) exemplifying the DIan-pattern, the constituent dis immoratalibus is a focus and, therefore, is placed at the end of the clause, which is normal for focal elements, whereas gratias appears in the initial position. The pragmatic dimension is here more important, than the others. In (17), on the contrary, dis bears a function of the discourse topic, which normally occupies the initial position, and besides, this is an animate noun with a very high status, so its prominence is determined by both the pragmatic and the denotative dimension. As regards the passage (18), which in Cicero's work appears immediately after the excerpt represented in (17), gratias bearing the function of the contrastive focus (in relation to quod bonus vir) is placed in the prominent position before the topical element dis, so in the competition of the three dimensions, the pragmatic dimension is a winner again.

There is a construction in the table, which is worth particular attention. This is dolorem dare / afferre / facere, which is, by contrast with gratias agere, attested only 8 times in my corpus, and almost exclusively in a single combination IproD, with pronominal Dative complement promoted in the front position, which highlights, in my opinion, the importance of deictic properties of arguments in the constructions under consideration. Thus in (19), the initial position of mihi placed before dolorem, is due to its locutor (i. e. speech act participant) status:

(19) tantum enim mihi dolorem cruciatumque attulerunt errata aetatis meae, ut non solum animus a factis sed aures quoque a commemoratione abhorreant (Cic. Fam., 16, 21, 2)

'For the errors of my youth have caused me such grief and agony that not only do my thoughts shrink from what I have done, but my very ears shrink from hearing it talked about'.

Nevertheless, there is an example definitely demonstrating the pragmatically determined order DI in this SVC:

13 The emphatic elements are often placed in the prominent initial or final position (Spevak 2010, 47). 
(20) [neque vero desistit, ubicumque est, omnia in me maledicta conferre. nihil mihi umquam tam incredibile accidit, nihil in his malis tam acerbum.] sed augeo commemorando dolorem et facio etiam tibi (Cic. Att. 11, 8, 2)

'[And he does not cease, wherever he is, from heaping all sorts of abuse on me. It is the most surprising thing that ever happened to me and the bitterest of all my present sorrows.] But I increase my own sorrow, and yours too, by speaking of it' (transl. by E. O. Winstedt).

In this example, the constituent tibi, modified by the focusing particle etiam, ${ }^{14}$ with the underlying question 'to whom do I also make a trouble', definitely bears the focal function and thus stands in the very end of the sentence.

In some cases, the pragmatic factors can cooperate rather than compete with deictic ones, as in (21):

(21) quin illud maereo quod tibi non minorem dolorem illorum orbitas adferet quam mihi (Cic. QFr. 1, 3, 10)

'Rather I grieve that their orphan state will cause you no less sorrow than it does me' (transl. by W. G. Williams).

The priority position of tibi with respect to dolorem can be explained both by the higher status of the speech act participant and by the contrast with mihi. ${ }^{15}$

Interestingly, in my corpus the SVC dolorem dare / afferre / facere appears very rarely (8 occurrences) and exclusively in Cicero's speeches and letters. I think that in this particular case, it is allowed to talk about the SVC as belonging to the colloquial Latin.

As regards the constructions choosing the opposite order DI, I will focus on spem afferre / proponere / dare. Since the order DI proved to be neutral in the constructions with trivalent verbs, as it was shown above, one can state that the order of complements attested in the majority of occurrences of spem afferre / proponere / dare is definitely determined by the syntactic dimension. In some cases, however, the influence of pragmatic factors cannot be denied, as in (22) and (23). Thus, in (22) the priority position is given to tibi as a contrastive (in relation to aliis) pronoun:

(22) nam superioribus litteris non unis sed pluribus, cum iam ab aliis desperata res esset, tamen tibi ego spem maturae decessionis adferebam (Cic. QFrt. 1, 1, 1)

'For not in one, but in several of my previous letters, in spite of others having given up the idea in despair, I gave you hope of being able at an early date to quit your province' (transl. by W.G. Williams).

In (23), the placement of Fufio before spem is due to the focusing particle etiam modifying the dative complement and making it appear earlier: ${ }^{16}$

(23) ...qui in Asia sunt rerum exitum exspectant, Achaici etiam Fufio spem deprecationis adferunt (Cic. Att. 11, 16, 2)

14 About the focusing particles see Spevak 2010, 49-51.

15 About the sentence initial position of contrastive (or emphatic) pronouns see Spevak 2010, 95.

${ }^{16}$ As Spevak $(2010,49)$ has shown, the focusing particles signal the constituents that contrast with another, expressed or understood constituent, when this is contrary to expectations or presuppositions. The example in (23) seems to be the case. On the other hand, the initial position of Fufio may be due to the predilection of the Latin language for bringing constituents referring to people close together (Spevak 2010, 95) and hence, due to denotative properties of the constituent. In this case, the pragmatic and deictic factors interact with each other again. 
'Those who are in Asia are waiting to see how things turn out: those in Achaia too keep holding out to Fufius the hope that they will petition to pardon' (transl. by E. O. Winstedt).

To sum up, the ordering of the Direct and Indirect objects results from the competition or interaction of the three paradigmatic dimensions, i. e. semantic, pragmatic and deictic-denotative ones.

\subsection{Ordering of the complements and the problem of valency center}

The competition of paradigmatic dimensions can explain the alternation of different orderings within the same construction, but it cannot help explaining why some SVCs apparently prefer $I D$-, whereas others - DI-pattern. As it is clearly seen from the table, the ID-pattern occurs much more frequently in our corpus, but some SVCs still choose the opposite pattern, or distribute both patterns almost equally. The question arises what it depends on.

I suppose that this can depend on whether the support verb or the abstract noun, or their structural unity attaches the Indirect object.

It seems that the $I D$-order is chosen when the Indirect object depends on the abstract noun rather than on the verb or on the whole construction, as in gratias agere, auxilium ferre, dolorem dare / afferre / facere, bellum gerere. For some of them, the dependence on the noun is confirmed by the fact that, when used beyond the SVC, they admit complements in the same syntactic form as the SVC. ${ }^{17}$

Thus bellum governs the prepositional phrase cum + Abl. both in SVC bellum gerere and when used separately, as in (24):

(24) equidem ad pacem hortari non desino; quae vel iniusta utilior est quam iustissimum bellum cum civibus (Cic. Att., 7, 14, 3)

'As for me, I cease not to advocate peace. It may be on unjust terms, but even so it is more expedient than the justest of civil wars' (transl. by E. O. Winstedt).

For others, there are simple cognate verbs that admit complements in the same case as the SVC, so gratulor ${ }^{18}$ and auxilior are used with the Dative, like gratias agere and auxilium ferre, whereas belligero occurs with cum + Abl., like bellum gerere. I suppose that similar syntactic behavior of both the simple verb and the complex expression belonging to the same semantic field, can serve as an additional argument for the noun as a center of valency in the SVCs analyzed. ${ }^{19}$

The DI-order, on the contrary, seems to be normal for the SVCs with the complements depending either on the support verb or on the whole construction, such as iniuriam facere, bellum facere, spem afferre / proponere / dare, insidias facere / parare. ${ }^{20}$ Although it is not always easy to distinguish, whether a verb or the unity of a verb and a noun governs a complement, but the order DI may be, at least, regarded as characteristic of such a type of

\footnotetext{
17 See Spevak 2014, 202.

18 Different meanings of gratulor with human and non-human dative complements are analyzed in detail by Marini $(2014,382)$.

19 Rosén $(1981,144)$ also highlights that "there remains considerable doubt whether the dative can be regarded as selected by the auxiliaries such as facere or even dare (as in salutem dare alicui)".

${ }^{20}$ According to Rosén $(1981,142)$, in such cases it cannot be decided whether the dative is dependent upon the underlying verb.
} 
SVCs. Thus, in the SVC bellum facere, ${ }^{21}$ with its preferred complement order DI, the noun bellum does not attach a Dative complement, when used beyond the SVC, consequently, it is the verb facere or the whole construction that attaches the Dative and, therefore, can be regarded as a valency center.

It is clear that the alignment of the arguments contributes - to some extent - to the solving of valency problem in Latin support verb constructions, which is still far from the final solution.

\section{Conclusions}

The analysis of the 304 verbo-nominal constructions has demonstrated that the order Indirect - Direct object (ID) occurs almost three times as often as the opposite order $D I$. This is explained either by the influence of deictic-denotative properties of the constituents, such as animacy and locutor status, or by pragmatic factors (focus, emphasis, contrast etc.). These two language dimensions compete with each other as well as with the semantic dimension, which determines the priority of the Direct over the Indirect object in the unmarked (neutral) contexts.

It is also observed, that the ordering $I D$ is preferred by the constructions with valency center on the abstract noun, whereas DI-ordering is preferable when the verb or the unity of a verb and a noun governs the Indirect object.

Further investigation of the SVCs with prototypically trivalent verbs on the extended empirical base that will include archaic and late Latin texts, could help to make more precise the data obtained in the present study and to draw more reliable conclusions.

\section{References}

Baños Baños J.M. Verbos soporte e incorporación sintáctica en latín: el ejemplo de ludos facere. Revista de Estudios Latinos 2012, 12, 37-57.

Baños Baños J.M. Sobre la manera de 'hacer la guerra' en latín: bellum gero, belligero, bello, in: José Antonio Beltrán et al. (éds.), Otium cum dignitate : estudios en homenaje al profesor Jos Javier Iso Echegoyen, Zaragoza, Universidad de Zaragoza, 2013, 27-39.

Flobert P. Les verbes support en latin, in: Alfred Bammesberger et Friedrich Heberlein (éds.), Akten des VIII. internationalen Kolloquiums zur lateinischen Linguistik, Heidelberg, Winter, 1996, 193-99.

Fugier H. Le verbe latin 'incorpore'-t-il ses compléments? in: József Herman (éds.), Linguistic Studies on Latin: Selected Papers from the 6th International Colloquium on Latin Linguistics, Budapest, $23-$ 27 March 1991. Amsterdam, J. Benjamins, 1994, 75-90.

Hofmann J. B., Szantyr A.Lateinische Syntax und Stilistik mit dem allgemeinen Teil der lateinischen Grammatik. München, C. K. Beck, ${ }^{2} 1972$.

Hoffmann R. On Sentential Complements of Latin Function Verb Constructions, in: Gerd V. M. Haverling (ed.), Latin Linguistics in the Early 21st Century. Acts of the 16th International Colloquium on Latin Linguistics, Uppsala, June 6th-11th, 2011. Uppsala, 2015, 362-373.

Giry-Schneider J. Les Prédicats nominaux en français: les phrases simples à verbe support. Genève, Droz, 1987. Gross G. Introduction, in: G. Gross et S. de Pontonx (ed.), Verbes supports: Nouvel état des lieux. Special issue of Lingvisticae Investigationes 2004, 27 (2), 167-169.

Gross M. Les bases empiriques de la notion de prédicat sémantique, Langages 1981, 63, 7-52.

Marini E. Les verbes à incorporation de l'objet en latin: essai d'aperçu typologique, in: Gerd V. M. Haverling (ed.), Latin Linguistics in the Early 21st Century. Acts of the 16th International Colloquium on Latin Linguistics, Uppsala, June 6th-11th, 2011. Uppsala, 2015, 116-132.

${ }^{21}$ See example (12). 
Marini E. Deux demarches pour un lexique-grammaire des verbs supports latins, in: Christian Lehmann et Concepción Cabrillana (éd.), Acta XIV Colloquii Internationalis Linguisticae Latinae, Madrid, Ediciones Clásicas, 2014, 373-389.

Pinkster H. The Oxford Latin Syntax. Oxford, Oxford University Press, 2015.

Rosén H. Studies in the Syntax of the Verbal Noun in Early Latin. Munich, Fink, 1981.

Spevak O. Constituent Order in Classical Latin Prose. Amsterdam - Philadelphia, Benjamins, 2010.

Spevak O. Noun Valency in Latin, in: Olga Spevak (ed.), Noun Valency. Amsterdam Philadelphia, Benjamins, 2014.

Taous T. A la recherche d'une dimension morphosémantique de la locution verbale: Arrêt sur quelques locutions en bellum/-a et manum/-ūs, in: Gerd V. M. Haverling (ed.), Latin Linguistics in the Early 21 st Century. Acts of the 16th International Colloquium on Latin Linguistics, Uppsala, June 6th-11th, 2011. Uppsala, 2015, $374-386$.

Valli A. À propos de la notion de locution verbale: Examen de quelques constructions à verbe support en moyen français. Langue Française 2007, 156, 45-60.

Zheltov A. Iazyki niger-kongo: strukturno-dinamicheskaya tipologiya [The Niger-Congo languages: structuraldynamic typology]. St.Petersburg, St.Petersburg State University Press, 2008.

Zheltova E. V.Deiktiko-denotativnaia ierarkhiia i konstruktsii s trekhvalentnymi glagolami v latinskom iazyke [Animacy Hierarchy and Three Valency Verb Constructions in Latin]. Philologia classica 2014, 9, 228-247.

Zheltova E. V. Pochemu reka odushevlennee raka: o nestandartnykh sluchaiakh proiavleniia kategorii odushevlennosti v latyni [Why 'River' is More Animate than 'Cancer': Explaining Some Unusual Cases of Animacy in Latin]. Philologia classica 2015, 10, 245-266.

For citation: Zheltova E. On the Order of Complements in Latin Support Verb Constructions: a Multidimensional Approach. Philologia Classica 2016, 11(2), 269-281. DOI: 10.21638/11701/spbu20.2016.206

\section{К ВОПРОСУ О ПОРЯДКЕ ДОПОЛНЕНИЙ \\ В ЛАТИНСКИХ АНАЛИТИЧЕСКИХ ГЛАГОЛЬНО-ИМЕННЫХ КОНСТРУКЦИЯХ: МНОГОУРОВНЕВЫЙ ПОДХОД}

Елена Владимировна Желтова

В статье исследуются латинские аналитические глагольно-именные конструкции типа bellum inferre или insidias facere $c$ прототипически трехвалентными глаголами, которые в составе таких конструкций могут терять одну из своих валентностей. После краткого обзора проблем, связанных с изучением данных конструкций, автор подробно останавливается на анализе порядка прямого и косвенного дополнений в 9 конструкциях, встречающихся у римских прозаиков классической эпохи (всего 304 употребления). Применяемый автором метод исследования базируется на идее о взаимодействии и конкуренции трех парадигматических измерений - семантического, прагматического и дейктико-денотативного, - которые могут влиять на порядок дополнений. Основываясь на данных, полученных в результате исследования аргументной структуры латинских трехвалентных глаголов, автор предлагает считать порядок «прямое-косвенное дополнение» немаркированным (нейтральным), а противоположный порядок объясняет действием дейктико-денотативных или прагматических факторов. Что касается влияния дейктико-денотативных свойств, выдвижение косвенного дополнения в приоритетную позицию может объясняться одушевленностью имени или статусом участника речевого акта у местоимения. Проведенный автором анализ порядка дополнений в аналитических глагольно-именных конструкциях показал, что порядок «косвенное - прямое дополнение» превалирует над противоположным, поскольку косвенные дополнения в большинстве случаев выражены одушевленными именами или личными / возвратными /анафорическими местоимениями. Что касается прагматических факторов, то фокус, эмфаза и контрастивность тоже могут влиять на порядок дополнений. Тот факт, что различные конструкции отдают предпочтение неодинаковым порядкам дополнений, объясняется разными центрами валентностей у каждой конструкции. Результаты исследования представлены в таблице и сопровождаются примерами.

Ключевые слова: латинские аналитические глагольно-именные конструкции, порядок слов, синтаксис, прагматика, дейктико-денотативные свойства имен, центр валентности. 